JETE : VOL 2 NO $12021 *$ E-ISSN : 2745-9888* P-ISSN : 2745-9896

Journal of Education and Teaching

http://ejournal.uin-suska.ac.id/index.php/JETE

\title{
FAKTOR PERSONALITAS DAN SOSIOKULTURAL DALAM PEMBELAJARAN BAHASA
}

\author{
Elita Fitri Yana ${ }^{1}$, Dr. Nursalim, M.Pd ${ }^{2}$ \\ ${ }^{12}$ UIN Sultan Syarif Kasim Riau, Indonesia \\ Email: elita@gmail.com nursalim@uin-suska.ac.id
}

\author{
Received: 30 Oktober 2019; Accepted 28 Mei 2021; Published 29 Mei 2021 \\ Ed 2021; 2(1): 123-132
}

\begin{abstract}
ABSTRAK
Mempelajari bahasa merupakan pekerjaan yang panjang dan berkelanjutan. Hal ini tentu melibatkan berberapa aspek, baik aspek intelektual, respon fisik, maupun aspek emosional. Personaliti atau kepribadian dalam diri seseorang merupakan faktor yang dapat membantu bagi kesuksesan dan keberhasilan proses pembelajaran bahasa. Kepribadian seseorang berperan penting dalam proses pengiriman dan penerimaan pesan melalui bahasa. Ini berarti, bahwa kepribadian akan ikut menentukan terhadap keberhasilan penerimaan bahasa ke dua. Budaya adalah bagian integral dari interaksi antara bahasa dan pikiran. Faktor sosial dan kultur atau budaya memiliki hubungan yang sangat erat dengan pembelajaran bahasa. Setiap kali kita mengajarkan satu bahasa, kita juga mengajarkan satu sistem keseluruhan tentang kebiasaan budaya, nilai-nilai,cara berpikir, merasa, dan bertindak. Permasalahan ini akan dijawab dalam tulisan inni menggunakan penelitian kepustakaan (library reaserch) yang akan menjawab apa saja faktor faktor personalitas dan sosiokultural yang dapat mempengaruhi proses pembelajaran bahasa. Data-data yang dikumpulkan dari berbagai referensi; baik primer, skunder maupun data pendukung.
\end{abstract}

Kata Kunci: personalitas, sosisokultural, pembelajaran, bahasa

\begin{abstract}
Learning languages is a long and sustainable work. This certainly involves several aspects, both intellectual aspects, physical responses, and emotional aspects. Personality or personality in a person is a factor that can help the success and success of the language learning process. A person's personality plays an important role in the process of sending and receiving messages through language. This means that personality will determine the success of the second language acceptance. Culture is an integral part of the interaction between language and mind. Social and cultural or cultural factors have a very close relationship with language learning. Every time we teach one language, we also teach an entire system of cultural habits, values, ways of thinking, feeling, and acting. This problem will be answered in this paper using library research (library reaserch) which will answer any personality and sociocultural factors that can affect the language learning process. Data collected from various references; both primary, secondary and supporting data.
\end{abstract}

Keywords: personality, sociocultural, learning, language 


\section{PENDAHULUAN}

Mempelajari bahasa adalah pekerjaan yang panjang dan berkelanjutan. Hal ini tentu saja karena mempelajari bahasa melibatkan berberapa aspek, baik aspek intelektual, respon fisik, maupun aspek emosional. Aspek-aspek tersebut sangat dibutuhkan dalam keberhasilan mengirim dan menerima pesan melalui bahasa. Mempelajari bahasa merupakan perjuangan untuk melampaui batasan- batasan bahasa pertama menuju dan berusaha menggapai bahasa baru, budaya baru, dengan cara baru dalam berpikir serta bertindak. Lebih jauh lagi mempelajari bahasa berarti berusaha menggapai bahasa baru yaitu bahasa kedua. Adapun salah satu definisi kepribadian adalah peneyesuaian. Menurut alexander A. Schneiders (1964) peneyesuaian ini dapat diartikan suatu proses respon individu yang baik bersifat behavioral maupun mental dalam upaya mengatasi kebuuhan-kebutuhan dari dalam diri, tegangan emosi, frustasi dan konflik serta memelihara keharmonisan antara kesatuan antara pemenuhan kebutuhan tersebut dengan norma yang ada dilingkungan.

Kepribadian seseorang menentu- kan kemampuan penyesuaian diri yang sifatnya unik terhadap lingkungannya. Jadi setiap individu memiliki kepribadian yang khas yang tidak identik dengan orang lain dan tidak dapat diganti atau disubstitusikan oleh orang lain. Jadi ada ciri-ciri atau sifat-sifat individu pada aspek-aspek psikhisnya yang bisa membedakan dirinya dengan orang lain. Kepribadian mencakup struktur dan proses yang mencerminkan sifat-sifat bawaan dan pengalaman. Personality atau kepribadian dalam diri seseorang, merupakan faktor yang membantu bagi kesuksesan dan keberhasilan pembelajaran bahasa. Kepribadian seseorang berperan penting dalam proses pengiriman dan penerimaan pesan melalui bahasa. Maksudnya bahwa kepribadian akan ikut menentukan terhadap keberhasilan penerimaan bahasa ke dua. Oleh karena itu, dalam tulisan ini akan dibahas tentang "faktor Personality dan sosiokultura dalam Pembelajaran Bahasa". Dalam proses pembelajaran bahasa banyak faktor yang mendukung keberhasilan pencapaian tujuan pembelajaran tersebut dan salah satunya adalah faktor-faktor sosiokultural. Faktor sosial dan kultur atau budaya memiliki hubungan yang erat dengan bahasa. Setiap kali kita mengajarkan satu bahasa, kita juga mengajarkan satu sistem yang kompleks tentang kebiasaan budaya, nilai-nilai, cara berpikir, merasa, dan bertindak (H. Douglas Brown, 2000: 65).

Bahasa selain sebagai salah satu unsur kebudayaan bisa juga manusia memanfaatkan pengalaman- pengalamannya mempelajari dan mengambil bagian dalam pengalamanpengalaman itu serta belajar berkenalan dengan orang-orang lain. Antara anggota masyarakat disuatau wilayah hanya dapat dipersatukan secara efisien melalui bahasa. Bahasa sebagai alat komunikasi lebih jauh memungkinkan tiap orang untuk merasa dirinya terikat dengan kelompok sosial yang dimasukinya serta dapat melakukan semua kegiatan kemasyarakatan dengan menghindari sejauh mungkin bentrokan-bentrokan untuk memperoleh efisiensi yang setinggi-tingginya. Bahasa memungkin- kan integrasi (pembauran) yang sempurna bagi tiap individu dengan dimasyarakatnya.

Melalui bahasa seorang anggota masyarakat perlahan-lahan belajar mengenal adat istiadat tingkah laku dan tata krama masyarakatnya. Ia mencoba menyesuaikan dirinya (adaptasi) dengan semuanya melalui bahasa. Seorang pendatang baru dalam sebuah masyarakat pun harus melakukan hal yang sama. Bila ingin hidup tenteram dan harmonis dengan masyarakat itu ia harus menyesuaikan dirinya dengan masyarakat itu, untuk itu ia 
memerlukan bahasa sebagai alat untuk bergaul, yaitu bahasa masyarakat tersebut. Bila ia dapat menyesuaikan dirinya maka ia pun dengan mudah menyatukankan dirinya (integrasi) dengan segala macam tata- krama masyarakat tersebut.

Bahasa menunjukkan perbedaan antara satu dengan yang lainnya, tetapi masingmasing tetap mengikat kelompok penuturnya dalam satu kesatuan. Setiap individu memungkinkan untuk menyesuaikan dirinya dengan adat istiadat dan kebiasaan bahasa yang ada dalam masyarakat itu. Dua orang yang mempergunakan bahasa yang sama akan mempergunakan pula kata-kata yang sama untuk melukiskan suatu situasi yang identik. Kata sebagai sebuah simbol bukan saja melambangkan pikiran atau gagasan tertentu, tetapi juga melambangkan perasaan keinginan dan tingkah laku seseorang. Dalam tulisan ini akan memaparkan pengertian tentang budaya, juga hubungan antara belajar bahasa kedua dan belajar konteks budaya bahasa kedua tersebut. Beberapa topik akan dibahas diantaranya adalah jarak sosial (social distance), budaya dalam kelas, kebijakan politik dan kebahasaan, bahasa-budaya dan pikiran, juga beberapa contoh penerapannya dalam pengajaran bahasa di kelas.

\section{METODE}

Penelitian ini adalah penelitian kepustakaan atau library research. Penelitian ini bertujuan untuk mengkaji teks, buku-buku dan naskah publikasi mengenai alam semesta meluas. Kajian ini diambil dari naskah- naskah kepustakaan yang relevan dengan topik penelitian yaitu berkaitan dengan topik yang dibahas. Sumber data yang digunakan adalah data-data hasil penelitian terdahulu yang relevan. Langkah-langkah yang dilakukan diantaranya pengumpulan data pustaka, membaca, mencatat, serta membandingkan literatur untuk kemudian diolah dan menghasilkan kesimpulan. Data yang digunakan merupakan data skunder berasal dari teksbook, jurnal, article ilmiah dan literature review yang berisikan tentang konsep yang sedang dikaji. Penelitian ini merupakan penelitian analisis kebutuhan yang nantinya digunakan sebagai dasar faktor personality dan sosiokultural dalam pembelejaran bahasa

\section{PEMBAHASAN}

\section{Teori Faktor Personalitas Dalam Pembelajaran Bahasa}

Personality atau kepribadian merupakan kesatuan organisasi yang sifatnya dinamis dari sistem psikhofisis individu. Kepribadian ini dapat menentukan kemampuan dalam penyesuaian diri yang sifatnya unik terhadap lingkungan disekitarnya. Kepribadian mencakup struktur dan proses yang mencerminkan sifat-sifat bawaan dan pengalaman. Kepribadian dipengaruhi oleh masa lalu dan saat ini (pervin, 1996). Karakteristik tipe kepribadian ada dua yaitu tipe kepribadian ekstrover dan tipe kepribadian introver. Kepribadian ekstrover adalah suatu kecenderungan yang mengarahkan kepribadian lebih banyak keluar dari pada ke dalam dirinya. Karakteristik ekstrover adalah banyak bicara, ramah, suka bertemu dengan orang-orang, suka mengunjungi tempat baru, aktif, menuruti kata hati, suka berpetualang, mudah bosan, dan tidak suka hal-hal yang rutin dan monoton (Larsen, 2002).

Hall dan Lindzey (1998) mengemukakan, bahwa orang dengan kepribadian ekstrover mudah bersosialisasi, senang hura-hura, mempunyai banyak teman, membutuhkan orang 
untuk diajak bicara, tidak suka membaca atau belajar sendiri, butuh kegembiraan, berani ambil risiko, selalu mempertahankan pendapatnya, bertindak tanpa dipikir dulu, menurutkan kata hati (impulsif), suka melawak, selalu mempunyai jawaban yang segar, dan umumnya menyukai perubahan, periang, supel, dan optimis.

Adapun orang dengan kepribadian introver merupakan suatu orientasi ke dalam diri sendiri. Orang introver cenderung menarik diri dari kontak sosial, pendiam, menjauhkan diri dari kejadian-kejadian luar, tidak mau terlibat dalam dunia objektif, dan tidak senang berada di tengah kerumunan banyak orang. Selain itu, karakteristik introver adalah pemalu, introspektif, lebih menyukai buku daripada manusia, suka menyendiri, dan tidak ramah kecuali pada teman dekatnya (Hall dan Lindzey, 1998). Kepribadian introver cenderung merencanakan segala sesuatu dengan hati-hati, dan tidak mudah percaya kata hati. Tipe kepribadian ekstrover dan introver merupakan dua kepribadian yang berbeda, dua kelompok sikap yang berbeda pada masing-masing individu yang menjadi ciri khas individu tersebut. Perbedaan ini sangat terlihat pada aktivitas, kesukaan bergaul, keberanian mengambil risiko, kedalaman berpikir dan tanggung jawab. Akan tetapi, baik individu yang ekstrover maupun yang introver tidak ada perbedaan dalam aktivitas intelektualnya.

Douglas Brown (2007), mengemukakan bahwa faktor kepribadian dalam proses pembelajaran bahasa melibatkan ranah afektif. Afeksi merujuk pada emosi atau perasaan. Ranah afektif adalah sisi emosional perilaku manusia, dan bisa disandingkan dengan sisi kognitif. Perkembangan keadaan afektif atau perasaan melibatkan beragam faktor, perasaan tentang diri kita maupun tentang orang lain yang berhubungan dengan diri kita.

Benjamin Bloom dan koleganya (1964), menyediakan sebuah teori tentang wilayah afektif yang masih banyak dipakai hingga sekarang diantaranya: 1) Perkembangan afeksi dimulai dengan menerima. Orang per orang harus mengerti lingkungan sekitar mereka dan menyadari, situasi, fenomena, orang-orang, dan benda- benda. Mereka harus bersedia menerima tenggang rasa sebuah stimulus bukan menghindarinya; 2) Orang per orang wajib mau menanggapi terhadap sebuah fenomena atau seseorang. Dimulai dengan tanggapan pasif, berlanjut pada tanggapan yang lebih tinggi secara sukarela, tanpa paksaan yang akhirnya akan mendapat kepuasan dari tanggapan tersebut; 3) Tataran ketiga afektivitas melibatkan penilaian, memberi harga pada sesuatu atau sebuah perilaku, atau seseorang; 4) Tataran wilayah afektif yang keempat, adalah pengorganisasian nilai-nilai ke dalam sistem kepercayaan; 5) Akhirnya individu-iindividu dicirikan oleh dan memahami diri sendiri selaras dengan sistem nilai mereka. Individu-individu bertindak secara konsestan sesuai dengan nilainilai yang mereka tanamkan dan menyatukan keyakinan, ide dan sikap ke dalam sebuah filosofi total atau pandangan hidup.

Pembelajaran bahasa ada keterkaitan atau hubungan dengan kecerdasan khususnya dalam pembelajaran dan pemerolehan bahasa kedua. Akan tetapi, hubungan yang terlihat hanya sedikit. Sebab orang dari berbagai tingkat IQ terbukti berhasil dalam menguasai bahasa kedua. Berbagai teori pembelajaran ruang kelas bahasa sudah sering diungkapkan, dan berikut ini adalah dua metode pembelajaran bahasa dari abad lalu yang perlu untuk dicermati yaitu: Metode Audiolingual (ALM), dan Metode Pembelajaran Bahasa Komunitas atau Comunity Language Learning (CLL). Personality atau kepribadian adalah salah satu faktor dalam diri 
seseorang yang dengan suatu cara memberikan sumbangan bagi kesuksesan pembelajaran bahasa. Sebagai bagian dari kepribadian ekstroversi dan introversi, juga berpotensi menjadi faktor-faktor penting dalam pemerolehan bahasa khususnya bahasa kedua.

\section{Faktor Sosiokultural Dalam Pembelajaran Bahasa}

Kultur atau budaya adalah pengetahuan yang diperoleh secara socially acquired knowledge. Pengetahuan ini diperoleh dari orang lain di dalam lingkungan sekelilingnya; bisa melalui petunjuk langsung atau dari mengamati perilaku mereka (R.A. Hudson, 1988: 77). Budaya juga didefinisikan sebagai gagasan, kebiasaan, keahlian, seni, dan peralatan (tools) yang menjadi ciri satu kelompok masyarakat pada suatu masa tertentu. Tapi budaya bukan hanya sekedar kumpulan dari bagian-bagian kecil. Larson dan Smalley dalam Brown (2000:176) memandang budaya sebagai penuntun tingkah laku seseorang dalam suatu komunitas; budaya membuat orang peka terhadap suatu masalah, dan budaya juga menolong kita untuk mengetahui apa yang orang lain harapkan dari kita (H. Douglas Brown, 2000: 176). Kenyataannya memang tidak ada satupun kelompok masyarakat yang tidak mempunyai budaya.

Stereotipe Budaya Dalam pertukaran budaya, kita dapat menyadari bahwa semua aspek yang ada dalam budaya yang masuk akan bercampur dengan budaya kita, baik budaya positif maupun negatif. Tentu saja pandangan seseorang tentang budaya yang masuk itu berbeda-beda. Jika seseorang terbiasa berpandangan tertutup (close-minded) maka mereka tidak akan bisa menerima perbedaan-perbedaan dari budaya orang lain. Dan hal-hal seperti itulah yang menyebabkan sebuah 'stereotype'. Stereotype melukiskan tipikal dari anggota masyarakat itu sendiri. Contohnya, ada anggapan bahwa orang Amerika semuanya kaya, santai, matrealistis, terlalu ramah, dan suka minum kopi. Orang Italia umumnya selalu penuh gairah (passionate), kekasih yang hebat, dan suka minum anggur merah. Sedangkan orang Inggris sopan, pelit, dan suka minum teh.

Stereotype bisa jadi dalam menduga watak 'umum' anggota budaya tertentu tapi tidak akurat untuk menggambarkan satu individu karena setiap orang memiliki keunikannya masing-masing. Oleh karena itu stereotyping atau pelabelan seseorang dari budaya berbeda haruslah dihindari baik pebelajar maupun guru bahasa kedua harus memahami perbedaan budaya, menyadari bahwa setiap orang berbeda-beda dan menghormati perbedaan tersebut.

\section{Attitudes (sikap)}

Menurut Gardner (1979), sikap memengaruhi motivasi yang pada akhimya akan mempengaruhi pemerolehan bahasa kedua atau Second Language Acquisition-SLA (Diane Larsen Freeman, Michael H. Long, 1992: 173); dengan kata lain sikap memiliki efek penting namun tidak langsung terhadap SLA. Salah satu sikap yang paling banyak diteliti adalah sikap si pebelajar terhadap para pembicara (speakers) bahasa sasaran (target languageTL.) tersebut. Makin positif sikap si pebelajar maka akan makin bagus pula kemajuan belajarnya..

Sebuah studi dilakukan oleh Hermann (1980) yang meneliti satu kelompok yang terdiri dari 750 anak- anak Jerman yang sedang belajar bahasa Inggris sebagai bahasa asing (Diane Larsen Freeman, Michael H. Long, 1992: 175). la menemukan bukti bahwa anak anak 
yang sudah belajar bahasa Inggris selama lima tahun menunjukkan sikap positif yang jauh lebih tinggi terhadap budaya sasaran (target culture) dibandingkan kelompok yang baru mulai belajar bahasa Inggris. Kesimpulan Hermann adalah: kepuasan yang didapatkan pebelajar dari prestasinya dalam kegiatan belajar bisa mempengaruhi sikapnya terhadap suatu kelompok ethnolinguistic bahkan dapat menghasilkan perubahan sikap. Jadi, bisa disimpulkan bahwa sikap dan kemajuan belajar sangat terkait erat dan mempengaruhi satu sama lain.

Meneliti lebih dalam lagi, menurut Freeman dan Long (1991) ada beberapa faktor lain yang juga mempengaruhi sikap dan motivasi pebelajar untuk mempelajari satu bahasa. Yaitu :

a. Orang Tua

Beberapa studi sudah menyelidiki peran orang tua dalam pembentukan sikap si pebelajar terhadap pengguna TL. Diantaranya Feenstra (1969) yang menyimpulkan bahwa anak- anak Anglophone di Canada yang belajar bahasa Perancis sebagai bahasa kedua di Montreal tidak harya mengadopsi sikap orang tuanya terhadap komunitas French Canada tapi sikap ini juga mempengaruhi prestasi anak-anak itu dalam mempelajari bahasa Perancis. Teman Sebaya (peers)

Penelitian Elias-Olivares (1976) menunjukkan bahwa generasi kedua Mexican American lebih suka memakai dialek calo daripada memakai bahasa Spanyol standar yang mereka pelajari di kelas bilingual. Hal ini dikarenakan anak- anak yang sudah lebih lama memakai calo akan mengolok-olok jika mereka berusaha bicara dengan bahasa standar.

\section{b. $\quad$ Guru}

Sikap guru terhadap murid sudah tentu dapat mempengaruhi kualitas pembelajaran itu sendiri. Bahkan Tucker dan Lambert (1973) menyatakan sikap guru lebih penting daripada sikap orang tua atau masyarakat dalam mempengaruhi hasil pemerolehan bahasa kedua.

c. Etnis

Kelompok etnis seseorang dapat menentukan sikap dan perilaku terhadap anggota kelompok lain yang pada akhirnya bisa mempengaruhi pembelajaran bahasa kedua/asing.

d. Akulturasi

Teori akulturasi ini berfokus pada pertanyaan kenapa pebelajar bahasa kedua, tidak seperti pebelajar bahasa pertama, kerap gagal mencapai kefasihan (mastery) bahasa sasaran. Penjelasannya disebut dengan istilah 'distance' atau

'jarak'. Pebelajar bahasa kedua bisa terputus aksesnya dengan penutur asli (dan berdampak juga pada input yang dibutuhkan) akibat jarak sosial atau jarak psikologis. Dalam kasus seperti ini maka perkembangan kemampuan pebelajar menjadi berhenti 'fossilizes' dan tidak ada perkembangan lebih lanjut pada interlanguage.

Akulturasi adalah proses modifikasi sikap, pengetahuan, dan perilaku dengan cara menambahkan elemen-elemen baru pada latar belakang budaya seseorang, mengurangi beberapa elemen yang sudah ada sebelumnya, dan penyusunan ulang (reorganisasi) elemeneleinen lain (Barry McLaughlin, 1989). Keseluruhan proses akulturasi tersebut membutuhkan adaptasi sosial dan psikologis.

Akulturasi dan pemerolehan bahasa kedua ditentukan oleh seberapa jauhnya jarak sosial (social distance) dan jarak psikologis (psychological distance) antara pebelajar dan budaya bahasa sasaran. Social distance berhubungan dengan individu sebagai anggota kelompok sosial yang berhubungan dengan kelompok sosial lain yang anggota-anggotanya 
bicara dengan bahasa berbeda. Sedangkan Psychological distance adalah hasil dari beragam faktor-faktor afektif yang menyangkut si pelajar sebagai individu, misalnya gegar budaya dan motivasi tinggi/rendah.

Gegar budaya (culture shock) adalah pengalaman yang sering terjadi pada pebelajar bahasa kedua pada budaya keduanya. Artinya, pebelajar itu belajar bahasa kedua di tempat yang baru dengan budaya yang baru juga. Gegar budaya identik dengan rasa asing, marah, frustasi, tidak senang, sedih, kesepian, bahkan sakit fisik. Gegar budaya ini digambarkan sebagai tahap kedua dalam pemerolehan budaya (culture acqusition), yang seluruhnya terdiri dari: 1) Euphoria dan excitement; 2) Gegar budaya (culture shock); 3) Culture stress; 4) Asimilasi dan adaptasi.

Akan tetapi, gegar budaya juga bisa dianggap sebagai sesuatu yang positif yaitu sebagai pengalaman be!ajar lintas budaya dimana seseorang menjadi sadar akan perkembangan, proses belajar, dan perubahan vang terjadi pada dirinya. Melalui pengalaman ini seseorang akan mendapatkan cara pandang yang berbeda atas dirinya sendiri dan memahami nilai- nilai, sikap, dan cara pandang orang lain yang diturunkan dari budaya mereka.

Social Distance (jarak sosial) John Schuman dalam Brown (2000:185) mendeskripsikan jarak budaya seperti di bawah ini: 1) Dominansi; sehubungan dengan kelompok bahasa target (Target Language Group), apakah kelompok pembelajar bahasa kedua (second language group-L2 group) tersebut dominan, non-dominan, atau subordinat secara politik, budaya, teknis, dan ekonomi? 2) Integrasi; bagaimana pola integrasi kelompok L2? Apakah secara asimilasi, akulturasi, atau preservasi? Apakah derajat/tingkat kelompok L2 saling terpisah? 3) Kepaduan; apakah kelompok L2 saling terpadu? Seberapa banyakkah anggota kelompok L2 tersebut; 4) Kesamaan; apakah ada kesamaan budaya antara kelompok L2 dan kelompok TL dalam hal sistem nilai dan kepercayaan? Bagaimana sikap- sikap keduanya satu sama lain; 5) Lama tinggal; Seberapa lamanya kelompok L2 berniat untuk tinggal di daerah TL?

Kelima faktor diatas digunakan pula oleh Schumann untuk mendeskripsikan situasi belajar bahasa yang 'baik' dan yang 'buruk'. Situasi belajar yang buruk adalah: Kelompok TL menganggap bahwa kelompok L2 dominan dan kelompok L2 pun beranggapan sama terhadap diri mereka. Kelompok L2 padu dan besar, budaya keduanya tidak sama, keduanya memiliki pandangan yang buruk satu sama lain, dan kelompok L2 bemiat untuk tinggal di wilayah TL sebentar saja.

Situasinya sama dengan poin 1 tapi kelompok L2 justru menganggap diri mereka sebagai kelompok minoritas dan dianggap demikian pula oleh kelompok TL.

Situasi belajar yang baik adalah: kelompok L2 tidak mendominasi kelompok TL. Keduanya saling berasimilasi atau minimal berakulturasi. Budaya keduanya mirip/sama Kelompok L2 hanya sedikit dan tidak begitu padu. Kedua kelompok saling menghargai. Kelompok L2 berniat untuk tinggal di wilayah TL lebih lama. Kondisi-kondisi inilah yang akan meminimalkan jarak atau kesenjangan dan pemerolehan bahasa target akan tercapai. Salah satu kelemahan hipotesis Schumann tersebut terletak pada cara pengukuran jarak yang ada, seberapa besar jarak tersebut, bagaimana cara mengukurnya, dan bagaimana cara pengukuran tersebut dapat menjadi tolak ukur perbandingan jarak yang ada. 
William Acton kemudian menentukan solusi dengan tes PDAQ (Professed Difference in Altitude Questionnare) yang mengkarakterisasi pebelajar bahasa yang baik/berhasil. Tes ini memiliki tingkat akurasi tinggi. Tes ini mencoba menggambarkan perbedaan- perbedaan konsep kata (misalnya 'perceraian' atau 'polisi') berdasarkan jarak antara pebelajar dengan masyarakat mereka sendiri secara umum, dengan anggota kelompok TL, dan antara masyarakat mereka sendiri dengan masyarakat kelompok TL.

Teori Acton didukung pula oleh Lambert yang berpendapat bahwa penguasaan bahasa asing terjadi seiring dengan kondisi/situasi di mana pebelajar telah 'keluar' dari budaya awalnya tapi belum seutuhnya berasimilasi dengan/ ke dalam budaya TL. Menurut optimal distance model (Brown: 1980) tentang pemerolehan bahasa kedua, orang dewasa yang gagal menguasai bahasa kedua dalam budaya kedua mungkin telah gagal menyelaraskan antara perkembangan linguistik dengan budaya.

Budaya dalam Kelas Tidak semua siswa dapat dengan mudah beradaptasi dengan budaya baru. Ada sebagian siswa yang mengalami hambatan psikologis dan efek-efek budaya lainnya. Siswa yang mengalami haI ini bisa merasa diasingkan oleh orang-orang disekitarnya dalam budaya kelompok TL. Keterasingan budaya ini dapat diatasi dengan teknik role-play (untuk berkomunikasi secara oral) dan menggunakan teknik lain seperti bacaan, film, atau pemainan simulasi.

Belajar bahasa yang baik adalah dengan mempelajari bahasa tersebut di wilayahnya, misalnya belajar bahasa Jepang di Jepang. Tapi kendalanya adalah siswa terkadang masih membawa dan cenderung menerapkan budaya aslinya ke dalam budaya barunya. Geert Hofstede dalam Brown (2000:190) menggunakan empat kategori untuk mempelajari norma budaya dari lima puluh negara yang berbeda: 1) Budaya individualisme melawan budaya kolektivisme. Dalam budaya individualis, seseorang dipandang berdasarkan kepentingannya sendiri atau kepentingan anggota keluarganya. Sedangkan dalam budaya kolektivisme, seseorang dipandang sebagai anggota kelompok/keluarga/marga/organisasi tersebut sejak kelahirannya; 2) Perbedaan derajat. Seseorang dengan posisi/pangkat yang tinggi akan diperlakukan dengan hormat sedangkan seseorang dengan pangkat rendah akan diperlakukan dengan rendah pula; 3) Menghindari kebingungan, dilakukan dengan cara menjaga tingkah laku dan sikap; 4) Gender. Ada budaya yang meletakkan semua peran sosial pada pihak lelaki (patrilineal); 5) Kebijakan Berbahasa dan Politik. Bicara tentang bahasa dan masyarakat tidak terlepas dari faktor- faktor politik tentang penggunaan bahasa dan kebijakan berbahasa.

Bahasa Inggris yang sekarang ini telah menjadi 'lingua franca' telah menimbulkan perdebatan internasional tentang pembuatan kebijakan berbahasa yang harus berhadapan dengan bermacam- macam legitimasi bahasa lnggris yang ada diantaranya: a) Status bahasa Inggris dalam keberagamannya; b) Munculnya konsep baru terhadap konteks penggunaan bahasa Inggris. Contoh: adanya bahasa Inggris Melayu di Malaysia dan Singapura, bahasa Inggris India di India. Hal ini dinamakan sebagai proses nativisasi atau pengaslian. ESL (English as a Second Language) dan EFL (English as a Foreign Language).; c) ESL berarti bahasa Inggris dipelajari sebagai bahasa kedua dan digunakan di negara tersebut. EFL berarti bahasa Inggris hanya dipelajari sebagai bahasa asing dan bukan sebagai bahasa sehari-hari. Pebelajar harus bisa membedakan status budaya dan sosiopolitikalnya dalam bahasa asli dan bahasa target, tujuannya mempelajari bahasa tersebut, dan intensitas motivasi pebelajar tersebut; a) Imperialisme linguistik dan hak- hak 
bahasa; b) 'Penjajahan' bahasa asli oleh bahasa asing (bahasa Inggris), Sebagai guru, kita harus waspada terhadap penerapan sistem nilai asing terhadap siswa; c) Kebijakan berbahasa dan kewajiban menggunakan bahasa Inggris

Satu lagi bentuk manifestasi penguasaan sosiopolitis di dunia ada pada kebijakan pemerolehan bahasa kedua. Kebijakan berbahasa bervariasi antara penggunaan bahasa dalam pendidikan anak dengan penggunaan bahasa secara resmi dalam suatu negara. Untuk mengatasinya diperlukan kehati-hatian dalam pembuatan kebijakan berbahasa karena bahasa akan dianggap sebagai suatu sistem nilai bagi generasi selanjutnya dalam masyarakat tersebut. Hubungan Bahasa, Pikiran, dan Budaya.

Perkembangan kognitif dan perkembangan linguistik berjalan beriringan dan berinteraksi satu sama lain. Cara sebuah gagasan/fakta dinyatakan mempengaruhi cara kita membentuk konsep tentang gagasan tersebut. Misalnya, persuasi dalam bahasa iklan, dalam ceramah seorang politisi, atau kisah menyentuh dalam sebuah novel.

Budaya adalah bagian integral dari interaksi antara bahasa dan pikiran. Contoh faktor budaya adalah gaya wacana percakapan. Misalnya, gaya obrolan santai di US tidak terlalu blak- blakan dibandingkan dengan gaya percakapan di Yunani. Pendapat bahwa bahasa dan budaya tidak bisa terpisahkan dipopulerkan oleh ahli-ahli Jerman seperti Johann, Herder (1803) dan Wilhelm von Humboldt (1835). Mereka menyatakan bahwa, different people speak differently because they think differently, and that they think differently because their language offers them different ways of expressing the world around them." (Kramsch, 1998: him 11).

Gagasan ini disebut sebagai linguistic relativity. Ide ini dikemukakan lagi di US oleh linguis Edward Sapir (1939) dan muridnya Benjamin Lee Whorf (1941) saat meneliti bahasa suku Hopi (Indian Amerika). Pandangan Whorf tentang saling ketergantungan antara bahasa dan pikiran dikenal dengan nama hipotesis Sapir-Whorf.

Hipotesis Sapir-Whorf mengatakan bahwa struktur bahasa yang kerap dipakai oleh seseorang mempengaruhi cara berpikir dan bertindak orang tersebut. Hipotesis ini menimbulkan banyak kontroversi sejak dirumuskan oleh Whorf pada tabun 1940.

Banyak orang tidak mau menerima ide bahwa bahasa menentukan pikiran (versi keras dari hipotesis ini) dan bukan sebaliknya. Namun sejalan dengan waktu, versi lemah hipotesis ini, yang didukung oleh penemuan-penemuan bahwa memang ada perbedaan budaya dalam asosiasi semantik yang dimunculkan oleh konsep-konsep yang tampakuya umum, dapat diterima secara luas. Contoh kasus bahasa anak Navajo membedakan antara kata kerja 'memungut benda bulat' seperti bola dengan 'memungut benda panjang, tipis, dan lentur' sepeiti tali. Saat disajikan tali biru, tali kuning, dan tongkat biru, lalu diminta memilih benda apa yang paling cocok dengan tali biru, hampir semua anak Navajo memilih tali kuning karena mengasosiasikan benda atas dasar bentuk fisik. Sedangkan anak berbahasa inggris hampir selalu memilih tongkat biru, mengasosiasikan dengan dasar warna, walau sebetulnya dua kelompok anak ini sama-sama bisa membedakan antara warna dan bentuk dengan baik.

Eksperimen ini mendukung versi lemah hipotesis Whorf bahwa para pengguna bahasa cenderung memilah dan membedakan pengalaman yarig mereka temui secara berheda-beda tergantung kategori semantik yang tersedia di bahasa masing-masing. Maka kita sebetulnya tidak terkurung oleh makna budaya yang ada dalam bahasa kita tapi kita juga bisa 
memperkaya makna tersebut melalui interaksi pragmatik dengan pengguna bahasa lain. Penerapan di Kelas Hubungan bahasa-budaya adalah faktor penting dalam pembelajaran bahasa kedua. Di dalam kelas guru bisa:

Membantu murid untuk menyadari tentang akulturasi dan tahap-tahapnya; Menekankan pentingnya bahasa kedua sebagai alat yang berguna untuk menyesuaikan diri di budaya yang baru; Lebih peka terhadap murid-murid yang nampaknya putus asa dan berusaha seoptimal mungkin untuk membantu mereka. Prinsip ini juga harus melandasi teknik-teknik yang dipakai guru bahasa asing di dalam kelas. Berikut adalah contoh checklist untuk menilai apakah teknik-teknik yang dipakai guru cocok secara budaya (Brown, 2000: hlm 202)

\section{SIMPULAN}

Pembelajaran bahasa ada keterkaitan dengan kecerdasan khususnya dalam pembelajaran dan pemerolehan bahasa kedua. Akan tetapi, hubungan yang terlihat hanya sedikit. Sebab orang dari berbagai tingkat IQ terbukti berhasil dalam menguasai bahasa kedua. Berbagai teori pembelajaran ruang kelas bahasa sudah sering diungkapkan, dan berikut ini adalah dua metode pembelajaran bahasa dari abad lalu yang perlu untuk dicermati yaitu: Metode Audiolingual (ALM), dan Metode Pembelajaran Bahasa Komunitas atau Comunity Language Learning (CLL). Personality atau kepribadian adalah salah satu faktor dalam diri seseorang yang dengan suatu cara memberikan sumbangan bagi kesuksesan pembelajaran bahasa. Sebagai bagian dari kepribadian ekstroversi dan introversi, juga berpotensi menjadi faktor-faktor penting dalam pemerolehan bahasa khususnya bahasa kedua. Faktor-faktor sosiokultural berkaitan erat dalam proses pembelajaran bahasa kedua dan bahasa asing. Dengan mengenali hubungan yang kompleks tersebut guru bahasa bisa merancang perlakuan apa yang oocok terhadap murid-muridnya di kelas, baik dari segi pendekatan maupun teknik. Guru juga dapat memberi pemahaman pada murid- murid tentang pentingnya memahami budaya kelompok pemakai bahasa sasaran jika mereka ingin menguasai bahasa tersebut dengan baik dan mencapai tingkat lahir.

\section{DAFTAR REFERENSI}

Al wasilah, A. Chaedar. 1985. Sosiologi Bahasa. Bandung Angkasa

Arlington VA.Pateda, Mansoer. 1987. Sosiolinguistik. Bandung: Angkasa.

Brown, Douglas, H. 2007. Prinsip Pembelajaran dan Pengajaran Bahasa. Copyright:

Chaer, Abdul dan Leonie Agustina. 2004. Sosiolinguistik Perkenalan Awal. Jakarta: Rineka Cipta.

Crystal, David. 1980. Afirst Dictionary of Linguistics and Phonetics. Great Britain : Andre Deush file//G:/net/hubungan-bahasa- seni-dan.html file///G:/net/PRANATA SOSIAL.htm http://abdullohaja.blogspot.com/2015/01

Hudson,R.A.1987. Sociologinguistics. Cambridge University Press. Cambridge. http://net/bahasa-dan-jenis kelamin.

Keraf, Gorys. 1994. Komposisi: Sebuah Pengantar Kemahiran Bahasa. Jakarta: Ikrar Mandiri Abadi.

Pearson Education, Inc.

Poedjosoedarmo, $\quad$ Soepomo. $\quad$ 1986. Ragam Panggung dalam Bahasa Jawa. Jakarta: Pusat

Suenjono Dardjowidjojo. 2008. Psikolinguistik, pengantar pemahaman bahasa manusia. Jakarta: Yayasan Obor Indonesia. 